\title{
Biometric characteristics of interspecific hybrids in the genus Secale
}

\author{
Sylwia Mikołajczyk ${ }^{1}$, Zbigniew Broda ${ }^{1}$, Danuta Mackiewicz ${ }^{1}$, \\ Dorota Weigt ${ }^{1}$, Agnieszka Tomkowiak ${ }^{1}$, Jan Bocianowski ${ }^{2}$ \\ ${ }^{1}$ Department of Genetics and Plant Breeding, Poznań University of Life Sciences, Dojazd 11, \\ 60-632 Poznań, Poland, e:mail: sylviam@au.poznan.pl \\ ${ }^{2}$ Department of Mathematical and Statistical Methods, Poznań University of Life Sciences, \\ Wojska Polskiego 28, 60-637 Poznań, Poland, e:mail: jboc@up.poznan.pl
}

\begin{abstract}
SUMMARY
Breeding work using European rye populations has resulted in a considerable reduction of genetic variation in breeding materials of that species. Many taxa from the genus Secale may constitute a potential source of genetic variation in rye breeding. A source of new genetic variation can be found in such species as Secale montanum and Secale vavilovii, which are sources of resistance to fusarium ear blight and septoria leaf blotch, while Secale vavilovii may also be a source of sterilising cytoplasm. The aim of this study was to assess the efficiency of crossing the wild species Secale vavilovii and the rye subspecies Secale cereale subsp. afghanicum, Secale cereale subsp. ancestrale, Secale cereale subsp. dighoricum, Secale cereale subsp. segetale with the crop species Secale cereale ssp. cereale, and to produce $F_{1}$ hybrids and describe selected morphological traits. Observations of biometric traits indicate that the $F_{1}$ crosses produced may be potential sources of variation for common rye. The greatest variation in terms of all analysed phenotypic traits combined was found for the cross combinations $S$. c. ssp. cereale cv. Amilo $\times S$. c. ssp. ancestrale and $S$. c. ssp. cereale cv. Dańkowskie Diament $\times S$. c. ssp. dighoricum. The hybrids showed considerable variation in the analysed biometric traits within individual cross combinations.
\end{abstract}

Key words: Secale genus, interspecific crossing, biometrical traits, $\mathrm{F}_{1}$ hybrids

\section{Introduction}

Breeding work using European rye populations has resulted in a considerable reduction of genetic variation in breeding materials of that species. The problem of the need to increase the genetic variation of rye has been analysed for many years, and wild species and subspecies of rye constitute a potential source of 
genes for economic traits. Few taxa from the genus Secale are crop species, but many may constitute a potential source of genetic variation in rye breeding. Interspecific crossing is a conventional and alternative method to genetic engineering techniques, being applied more and more commonly in the improvement of cereal cultivars (Feuillet et al., 2007; Pilch, 2011).

Changing requirements in contemporary plant breeding have resulted in renewed interest in the use of wild species to increase genetic variation in cereals, as rye cultivars have a significantly reduced genetic variation. It is desirable in this regard to focus particularly on such species as Secale montanum and Secale vavilovii, which are sources of resistance to fusarium ear blight and septoria leaf blotch, while Secale vavilovii may also be a source of sterilising cytoplasm in rye breeding (Pilch, 2011). In view of climate change and new biotic and abiotic stresses, there is a need to investigate related wild species and subspecies of rye, searching for new alleles of genes which may in the near future provide improved yields and quality of that cereal (Feuillet et al., 2007). Introgression of genes from wild species and restorer genes from primitive Iranian populations to rye cultivars may also lead to changes in yield levels and improved grain quality, as well as facilitating the application of the heterosis effect in the development of new cultivars (Falke et al., 2008; Pilch, 2011).

Rye is a cereal which remains an economically important species in areas of temperate climate and poor, acidified soils. The grain may be used in three main areas: for human consumption, as fodder, and for industrial purposes. There is a particular need to focus on the use of rye in the production of food with enhanced dietary value, alleviating the adverse effects of the so-called diseases of civilisation or lifestyle. Another aspect of the utilisation of this species is the use of rye straw as a potential energy source and a component in the production of particleboards (Jankiewicz, 2006).

Rye as a crop exhibits high tolerance to low temperatures, drought, salinity and acidity and to stress induced by aluminium ions, as well as disease resistance. The primary objectives in rye breeding are focused on grain yield, 
reduced culm length and resistance to sprouting, drought stress tolerance and nitrogen deficit, tolerance of soil acidity and high concentrations of aluminium, zinc and sodium ions, flour strength, feed quality, production of ethanol and biomethane, as well as the use of rye as a fodder crop (Geiger and Miedaner, 2009). Since one of the primary breeding objectives is connected with broadly defined abiotic stress, it is advisable to search for sources of tolerance in wild species from the genus Secale.

The changing needs and requirements of contemporary plant breeding, including breeding based on the heterosis effect, has resulted in renewed interest in wild species and subspecies of rye as potential donors of genes for functional traits. The present study assessed the suitability of rarely used wild species and subspecies of rye as components in distant crossings with cultivars of Secale cereale ssp. cereale. The aim was to enhance genetic variation in existing gene resources, based on wild species which had not been used previously as sources of genetic variation for rye: Secale sylvestre, and the rye subspecies Secale cereale ssp. afghanicum, Secale cereale ssp. ancestrale, Secale cereale ssp. dighoricum and Secale cereale ssp. segetale. This demonstrates the innovative nature of the present study carried out on this species.

The aim of the study was to assess the efficiency of crossing the wild species Secale vavilovii and the rye subspecies Secale cereale subsp. afghanicum, Secale cereale subsp. ancestrale, Secale cereale subsp. dighoricum, Secale cereale subsp. segetale with the crop species Secale cereale ssp. cereale, and to produce $F_{1}$ hybrids and describe selected morphological traits.

\section{Materials and Methods}

Material for interspecific crossing within the genus Secale was provided by the crop species Secale cereale subsp. cereale cultivars Amilo, Dańkowskie Diament and Skat, and the wild Secale vavilovii as well as the subspecies Secale cereale subsp. afghanicum, Secale cereale subsp. ancestrale, Secale cereale 
subsp. dighoricum and Secale cereale subsp. segetale. A total of 100 kernels were sown for each species and subspecies of wild rye and for the three cultivars. Species for crossing were selected based on similarities of developmental biology, potential for recombination between wild species and the crop species, as well as similar flowering dates for the purpose of crossing (Ćwiklińska et al., 2009). The wild species and subspecies used in the experiment came from the PAS Botanical Garden and Centre for Biological Diversity Conservation, while the cultivars came from Danko Plant Breeders Ltd., Choryń.

Simple and reciprocal crossing was performed. Crossing efficiency was calculated on the basis of the percentage of set kernels in relation to the number of pollinated culms. Next, seeds of the control cultivar Dańkowskie Diament and interspecific $F_{1}$ hybrids were sown in pots. Germination and plant growth up to the tillering phase took place in a greenhouse, and the plants were then vernalised under natural conditions. During plant growth, standard cultivation measures recommended for rye were applied.

Biometric measurements of quantitative traits (plant height, number of productive culms per plant, main spike length, number of spikelets per main spike, rachis length, spike density (D) and number of kernels per plant) were taken on plants at the complete maturity phase.

In order to obtain hybrids, 100 plants were produced from each species, subspecies and cultivar. Observations were conducted on 595 hybrid $F_{1}$ plants, obtained from 652 kernels. In measurements of biometric traits each hybrid $F_{1}$ plant was treated individually, and the results presented in the tables and figures represent mean values for each hybrid combination. Due to the variable numbers of plants in each combination of $F_{1}$ hybrids (from 6 to 80 plants) and the early stage of assessment of variation in the produced plant material, it was decided not to perform replications.

Firstly, the normality of distributions for studied traits as well as multivariate normality was tested. Multivariate analysis of variance 
(MANOVA) was performed based on the following model using the MANOVA procedure in GenStat 15 th edition:

$$
\mathbf{Y}=\mathbf{X T}+\mathbf{E},
$$

where $\mathbf{Y}$ is an $(n \times p)$-dimensional matrix of observations, $n$ is the number of all observations, $p$ is the number of traits, $\mathbf{X}$ is an $(n \times k)$-dimensional design matrix, $k$ is the number of hybrids, $\mathbf{T}$ is a $(k \times p)$-dimensional matrix of unknown effects, and $\mathbf{E}$ is an $(n \times p)$-dimensional matrix of residuals. All the parameters are unknown and have to be estimated under the usual assumptions concerning random errors, such as that of the same covariance matrix for each experimental unit and of no correlations between different experimental units.

Next, one-way analysis of variances (ANOVA) was performed to test the zero hypothesis of an absence of differences between hybrid combinations in terms of the values of observed traits, i.e. plant height, number of productive culms per plant, main spike length, number of spikelets per main spike, rachis length, spike density (D) and number of kernels per plant, for each trait independently, based on the following model:

$$
\mathrm{y}_{\mathrm{ij}}=\mu+\tau_{\mathrm{i}}+\varepsilon_{\mathrm{ij}},
$$

where: $y_{i j}$ is the $j$ th observation of the $i$ th hybrid, $\mu$ is the grand mean, $\tau_{i}$ is the effect of the $i$ th hybrid, and $\varepsilon_{i j}$ is an error observation.

Spike density in progeny was determined based on the index D expressed as the quotient of the number of spikelets in the main spike $\times 100$, as well as rachis length in $\mathrm{mm}$.

For individual traits, mean values and standard deviations (s.d.) were calculated. Fisher's least significant differences (LSD) were also estimated at the significance level $\alpha=0.001$. Interdependence between observed traits was assessed on the basis of Pearson's correlation coefficients calculated for means for hybrid combinations using the FCORRELATION procedure in GenStat 15th edition.

The results were also analysed using multivariate methods (Caliński and Kaczmarek, 1973; Rencher, 1992). Analysis of canonical variables was applied 
in order to present a multitrait assessment of the similarity of tested hybrid combinations and the control cultivar Dańkowskie Diament in a lower number of dimensions with the least possible loss of information (Rencher, 1992). This makes it possible to illustrate variation in combinations of hybrids and the cultivar Dańkowskie Diament in graphical form in terms of seven traits. Mahalanobis' distance was suggested as a measure of "polytrait" hybrid similarity (Seidler-Łożykowska and Bocianowski, 2012), whose significance was verified by means of the critical value $\mathrm{D}_{\alpha}$ called the "least significant distance" (Mahalanobis, 1936). All analysis was performed using the GenStat v. 15 statistical software package (Payne et al., 2012).

\section{Results}

In particular interspecific cross combinations, between 76 and 488 spikelets were pollinated and a total of 652 kernels were obtained (Table 1). The highest number of kernels (80) was produced in the hybrid combination Secale cereale ssp. cereale cv. Skat $\times$ Secale cereale ssp. afghanicum, where the crossing efficiency was $24.6 \%$. In turn, the highest crossing efficiency (51.4\%) was observed in the combination of Secale cereale ssp. cereale cv. Dańkowskie Diament $\times$ Secale cereale ssp. ancestrale, where the number of set kernels was 39 (Table 1). No grain was produced in cross combinations between:

- Secale cereale ssp. cereale cv. Amilo $\times$ Secale cereale ssp. segetale;

- Secale cereale $\mathrm{ssp}$. segetale $\times$ Secale cereale ssp. cereale cv. Dańkowskie Diament;

- Secale cereale $\mathrm{ssp}$. dighoricum $\times$ Secale cereale ssp. cereale cv. Amilo;

- Secale cereale ssp. ancestrale $\times$ Secale cereale ssp. cereale cv. Dańkowskie Diament;

- Secale cereale $\mathrm{ssp}$. cereale cv. Skat $\times$ Secale cereale $\mathrm{ssp}$. ancestrale;

- Secale cereale ssp. cereale cv. Amilo $\times$ Secale vavilovii.

All studied traits have a normal distribution as well as a multivariate normality. The results of MANOVA indicate that the hybrids were significantly 
Table 1. Efficiency of distant crossing between crop and wild species and subspecies of rye

\begin{tabular}{|c|c|c|c|c|}
\hline $\begin{array}{l}\text { Cross } \\
\text { comb. }\end{array}$ & $\begin{array}{l}\text { Combinations of simple and reciprocal crossing } \\
\qquad\left(\uparrow \mathrm{A} \times \supset^{\lambda} \mathrm{B} ; \uparrow \mathrm{B} \times \partial^{\lambda} \mathrm{A}\right)\end{array}$ & $\begin{array}{c}\text { Number of } \\
\text { pollinated } \\
\text { spikelets } \\
\text { [pcs.] }\end{array}$ & $\begin{array}{c}\text { Number of } \\
\text { produced } \\
\mathrm{F}_{1} \text { kernels } \\
\text { [pcs.] }\end{array}$ & $\begin{array}{c}\text { Crossing } \\
\text { efficiency } \\
{[\%]}\end{array}$ \\
\hline 1. & $\begin{array}{l}\text { Secale cereale ssp. afghanicum } \times \text { Secale cereale } \\
\text { ssp. cereale cv. Amilo }\end{array}$ & 488 & 21 & 4.3 \\
\hline 2. & $\begin{array}{l}\text { Secale cereale } \mathrm{ssp} \text {. cereale cv. Amilo } \times \text { Secale } \\
\text { cereale } \mathrm{ssp} \text {. Afghanicum }\end{array}$ & 315 & 46 & 14.6 \\
\hline 3. & $\begin{array}{l}\text { Secale cereale ssp. afghanicum } \times \text { Secale cereale } \\
\text { ssp. cereale cv. Dańkowskie Diament }\end{array}$ & 262 & 52 & 19.8 \\
\hline 4. & $\begin{array}{l}\text { Secale cereale ssp. cereale cv. Dańkowskie } \\
\text { Diament x Secale cereale ssp. afghanicum }\end{array}$ & 400 & 48 & 12.0 \\
\hline 5. & $\begin{array}{l}\text { Secale cereale ssp. afghanicum } \times \text { Secale cereale } \\
\text { ssp. cereale cv. Skat }\end{array}$ & 328 & 63 & 19.2 \\
\hline 6. & $\begin{array}{l}\text { Secale cereale ssp. cereale cv. Skat } \times \text { Secale } \\
\text { cereale ssp. Afghanicum }\end{array}$ & 325 & 80 & 24.6 \\
\hline 7. & $\begin{array}{l}\text { Secale cereale ssp. ancestrale } \times \text { Secale cereale } \\
\text { ssp. cereale cv. Amilo }\end{array}$ & 176 & 28 & 15.9 \\
\hline 8. & $\begin{array}{l}\text { Secale cereale } \mathrm{ssp} \text {. cereale cv. Amilo } \times \text { Secale } \\
\text { cereale ssp. Ancestrale }\end{array}$ & 82 & 6 & 7.3 \\
\hline 9. & $\begin{array}{l}\text { Secale cereale ssp. cereale cv. Dańkowskie } \\
\text { Diament } \times \text { Secale cereale ssp. ancestrale }\end{array}$ & 76 & 39 & 51.3 \\
\hline 10 & $\begin{array}{l}\text { Secale cereale ssp. ancestrale } \times \text { Secale cereale } \\
\text { ssp. cereale cv. Skat }\end{array}$ & 112 & 18 & 16.1 \\
\hline 11. & $\begin{array}{l}\text { Secale cereale } \mathrm{ssp} \text {. cereale cv. Amilo } \times \text { Secale } \\
\text { cereale } \text { ssp. Dighoricum }\end{array}$ & 126 & 14 & 11.1 \\
\hline 12 & $\begin{array}{l}\text { Secale cereale ssp. dighoricum } \times \text { Secale cereale } \\
\text { ssp. cereale cv. Dańkowskie Diament }\end{array}$ & 134 & 24 & 17.9 \\
\hline 13. & $\begin{array}{l}\text { Secale cereale ssp. cereale cv. Dańkowskie } \\
\text { Diament } \times \text { Secale cereale ssp. dighoricum }\end{array}$ & 98 & 8 & 8.2 \\
\hline 14. & $\begin{array}{l}\text { Secale cereale } \mathrm{ssp} \text {. dighoricum } \times \text { Secale cereale } \\
\text { ssp. cereale } \mathrm{cv} \text {. Skat }\end{array}$ & 105 & 16 & 15.2 \\
\hline 15. & $\begin{array}{l}\text { Secale cereale ssp. cereale cv. Skat } \times \text { Secale } \\
\text { cereale ssp. Dighoricum }\end{array}$ & 86 & 6 & 7.0 \\
\hline 16. & $\begin{array}{l}\text { Secale cereale } \text { ssp. segetale } \times \text { Secale cereale } \mathrm{ssp} \text {. } \\
\text { cereale } \mathrm{cv} \text {. Amilo }\end{array}$ & 180 & 9 & 5.0 \\
\hline 17. & $\begin{array}{l}\text { Secale cereale ssp. cereale cv. Dańkowskie } \\
\text { Diament } \times \text { Secale cereale } \text { ssp. segetale }\end{array}$ & 164 & 6 & 3.7 \\
\hline 18. & $\begin{array}{l}\text { Secale cereale ssp. segetale } \times \text { Secale cereale } \mathrm{ssp} \text {. } \\
\text { cereale } \mathrm{cv} \text {. Skat }\end{array}$ & 252 & 34 & 13.5 \\
\hline 19. & $\begin{array}{l}\text { Secale cereale ssp. cereale cv. Skat } \times \text { Secale } \\
\text { cereale } \text { ssp. Segetale }\end{array}$ & 336 & 60 & 17.9 \\
\hline \multirow[t]{2}{*}{20} & $\begin{array}{l}\text { Secale vavilovii } \times \text { Secale cereale } \text { ssp. cereale cv. } \\
\text { Amilo }\end{array}$ & 249 & 74 & 29.7 \\
\hline & total: & 652 & 214.7 & 16.6 \\
\hline
\end{tabular}


(Wilk's $\lambda=0.0002355 ; \mathrm{F}_{140,1645}=29.57 ; \mathrm{p}<0.0001$ ) different for all seven traits. The results of analysis of variance for seven biometric traits [plant height $\left(\mathrm{F}_{20,594}=16.23\right)$, number of productive culms per plant $\left(\mathrm{F}_{20,287}=22.17\right)$, main spike length $\left(\mathrm{F}_{20,380}=12.79\right)$, number of spikelets per main spike $\left(\mathrm{F}_{20,380}=341.29\right)$, rachis length $\left(\mathrm{F}_{20,380}=9.60\right)$, spike density $-\mathrm{D}$ $\left(\mathrm{F}_{20,376}=359.13\right)$, number of kernels per plant $\left.\left(\mathrm{F}_{20,257}=35.26\right)\right]$ confirm the difference between the tested $F_{1}$ hybrids and the control cultivar Dańkowskie Diament at the significance level $\alpha=0.001$ (Table 2).

Table 2. Mean squares (m.s.) from analysis of variance (ANOVA) of quantitative traits

\begin{tabular}{|c|c|c|c|c|}
\hline \multirow{2}{*}{ Source of variation } & \multicolumn{2}{|c|}{ Hybrid combinations } & \multicolumn{2}{|c|}{ Residual } \\
\hline & d.f. & m.s. & d.f. & m.s. \\
\hline Plant height & 20 & $2185.8 * * *$ & 594 & 134.7 \\
\hline Number of productive culms per plant & 20 & $111.2 * * *$ & 287 & 5.0 \\
\hline Main spike length & 20 & $29.9 * * *$ & 380 & 2.3 \\
\hline Number of spikelets per main spike & 20 & $7625.8 * * *$ & 380 & 22.3 \\
\hline Rachis length & 20 & $1683.3 * * *$ & 380 & 175.4 \\
\hline Spike density (D) & 20 & $8685.3 * * *$ & 376 & 24.2 \\
\hline Number of kernels per plant & 20 & $30484.2 * * *$ & 257 & 864.5 \\
\hline \multicolumn{5}{|c|}{$* * * \mathrm{p}<0.001$} \\
\hline
\end{tabular}

Mean values the observed phenotypic traits indicate high variation among the tested $F_{1}$ hybrids, for which significant differences were found in all of the analysed morphological traits (Table 3). Mean spike length ranged from 86.1 $\mathrm{cm}$ in the combination Secale cereale $\mathrm{ssp}$. cereale cv. Skat $\times$ Secale cereale $\mathrm{ssp}$. dighoricum, to $118.7 \mathrm{~cm}$ in the combination Secale cereale ssp. cereale cv. Skat $\times$ Secale cereale ssp. afghanicum. The mean number of productive culms per plant was lowest in the crosses Secale cereale ssp. dighoricum $\times$ Secale cereale ssp. cereale cv. Amilo and Secale cereale $\mathrm{ssp}$. dighoricum $\times$ Secale cereale $\mathrm{ssp}$. cereale cv. Dańkowskie Diament, and highest in the hybrid combination Secale vavilovii $\times$ Secale cereale ssp. cereale cv. Amilo, the values being 4.2 and 11.2 
Table 3. Mean values of selected phenotypic traits of $F_{1}$ interspecific hybrids of rye and cv. Dańkowskie Diament (DD)

\begin{tabular}{|c|c|c|c|c|c|c|c|c|}
\hline $\begin{array}{l}\text { Cross } \\
\text { comb. }\end{array}$ & $\begin{array}{c}\text { Number of } \\
\text { analyzed } \\
\text { plants }\end{array}$ & $\begin{array}{l}\text { Plant } \\
\text { height } \\
{[\mathrm{cm}]}\end{array}$ & $\begin{array}{c}\text { Number of } \\
\text { productive } \\
\text { culms per } \\
\text { plant }\end{array}$ & $\begin{array}{c}\text { Main } \\
\text { spike } \\
\text { length } \\
{[\mathrm{cm}]}\end{array}$ & $\begin{array}{c}\text { Number of } \\
\text { spikelets } \\
\text { per main } \\
\text { spike }\end{array}$ & $\begin{array}{l}\text { Rachis } \\
\text { length } \\
{[\mathrm{mm}]}\end{array}$ & $\begin{array}{c}\text { Spike } \\
\text { density } \\
{[D]}\end{array}$ & $\begin{array}{c}\text { Number of } \\
\text { kernels per } \\
\text { plant }\end{array}$ \\
\hline 1 & 20 & 112.2 & 6.5 & 14.6 & 34.8 & 100.5 & 35.1 & 22.5 \\
\hline 2 & 46 & 115.6 & 9.2 & 14.9 & 36.9 & 115.3 & 32.4 & 123.0 \\
\hline 3 & 54 & 116.0 & 6.1 & 13.2 & 22.5 & 95.6 & 23.7 & 33.5 \\
\hline 4 & 48 & 110.4 & 7.5 & 12.7 & 21.9 & 96.2 & 22.8 & 47.1 \\
\hline 5 & 59 & 110.2 & 9.2 & 14.4 & 23.0 & 100.5 & 23.2 & 57.8 \\
\hline 6 & 80 & 118.7 & 6.1 & 13.6 & 22.5 & 97.1 & 23.3 & 29.9 \\
\hline 7 & 28 & 111.1 & 7.0 & 13.3 & 21.2 & 89.0 & 23.9 & 79.4 \\
\hline 8 & 6 & 114.3 & 6.6 & 13.7 & 23.0 & 97.8 & 23.5 & 160.0 \\
\hline 9 & 39 & 108.1 & 6.6 & 14.3 & 22.5 & 101.2 & 22.1 & 23.7 \\
\hline 10 & 18 & 103.1 & 8.8 & 12.7 & 20.2 & 84.0 & 24.1 & 87.7 \\
\hline 11 & 15 & 99.5 & 4.2 & 13.3 & 56.5 & 90.9 & 62.4 & 32.3 \\
\hline 12 & 24 & 113.8 & 4.2 & 11.6 & 57.4 & 91.1 & 63.4 & 30.7 \\
\hline 13 & 8 & 89.2 & 4.3 & 13.6 & 59.2 & 100.3 & 59.2 & 21.2 \\
\hline 14 & 16 & 101.0 & 4.6 & 13.3 & 59.8 & 104.8 & 58.4 & 44.1 \\
\hline 15 & 6 & 86.1 & 4.3 & 13.8 & 56.0 & 101.8 & 56.2 & 37.1 \\
\hline 16 & 9 & 111.2 & 5.6 & 13.1 & 59.2 & 102.8 & 58.1 & 8.1 \\
\hline 17 & 6 & 108.0 & 5.0 & 14.1 & 54.0 & 101.2 & 53.4 & 16.3 \\
\hline 18 & 34 & 101.6 & 4.8 & 12.5 & 55.7 & 91.8 & 61.0 & 20.9 \\
\hline 19 & 59 & 102.5 & 4.8 & 12.5 & 58.1 & 100.9 & 57.9 & 15.5 \\
\hline 20 & 32 & 101.1 & 11.2 & 13.2 & 51.7 & 85.2 & 61.1 & 15.3 \\
\hline DD & 8 & 66.02 & 8.6 & 8.75 & 28.5 & 78.9 & 36.2 & 50.5 \\
\hline
\end{tabular}

$(\mathrm{p}<0.001)$ respectively. The lowest mean length of the main spike, at just 11.6 $\mathrm{cm}$, was found in Secale cereale ssp. dighoricum $\times$ Secale cereale ssp. cereale cv. Dańkowskie Diament, while the greatest value $(14.9 \mathrm{~cm})$ occurred in the cross Secale cereale ssp. cereale cv. Amilo $\times$ Secale cereale ssp. afghanicum $(p<0.001)$. In $F_{1}$ hybrids the number of spikelets per main spike varied. The lowest mean number of spikelets per main spike was recorded for plants of Secale cereale $\mathrm{ssp}$. ancestrale $\times$ Secale cereale $\mathrm{ssp}$. cereale $\mathrm{cv}$. Skat, while the greatest number was observed in $\mathrm{F}_{1}$ crosses of Secale cereale ssp. dighoricum $\times$ Secale cereale ssp. cereale cv. Skat, the values being 20.2 and $59.8(\mathrm{p}<0.001)$ respectively. Spike density was also found to be variable in the investigated populations. Dense spikes $(D>37)$ were observed in $F_{1}$ plants of the cross 
combination Secale cereale ssp. dighoricum $\times$ Secale cereale ssp. cereale cv. Amilo and in reciprocal crosses of Secale cereale ssp. cereale cv. Skat $\times$ Secale cereale ssp. dighoricum. Spikes of medium density $(\mathrm{D}=34-37 ; \mathrm{p}=0.037)$ were found in $\mathrm{F}_{1}$ crosses of Secale cereale ssp. afghanicum $\times$ Secale cereale ssp. cereale cv. Dańkowskie Diament, as well as reciprocal crosses of Secale cereale $\mathrm{ssp}$. cereale cv. Dańkowskie Diament $\times$ Secale cereale ssp. afghanicum and Secale cereale ssp. ancestrale $\times$ Secale cereale ssp. cereale cv. Skat. The other populations of $F_{1}$ crosses had loose spikes with spike density $D<34$. The mean number of kernels from $\mathrm{F}_{1}$ crosses ranged from 8.1 kernels for Secale cereale ssp. segetale $\times$ Secale cereale $\mathrm{ssp}$. cereale cv. Amilo up to 160 kernels for Secale cereale ssp. cereale cv. Amilo $\times$ Secale cereale ssp. ancestrale $(\mathrm{p}<0.001)$.

Hybrid plants of the $F_{1}$ generation also exhibited high variability, in all of the analysed phenotypic traits, within individual cross combinations. The range and medians for the seven analysed traits are presented on box plots (Figs. 1-7). The effect of crossing components on the phenotype is given in the graphs presenting the number of spikelets in the main spike and spike density, where plants produced by crossing cultivars with Secale cereale ssp. afghanicum and Secale cereale ssp. ancestrale have markedly lower values of these traits (Fig. 5 and Fig. 7).

Analysis of correlations indicates statistically significant negative correlations of the number of spikelets per main spike with the number of productive culms per plant $(\mathrm{r}=-0.55)$, the number of productive culms per plant with spike density $(r=-0.49)$, the number of spikelets per main spike with the number of kernels per plant $(\mathrm{r}=-0.51)$, and spike density with the number of kernels per plant $(r=-0.54)$. A significant positive interdependence was observed between plant height and main spike length $(r=0.62)$, main spike length and rachis length $(r=0.72)$, and number of spikelets per main spike and spike density $(r=0.98)$. Results of the analysis of correlations are given in Table 4. 


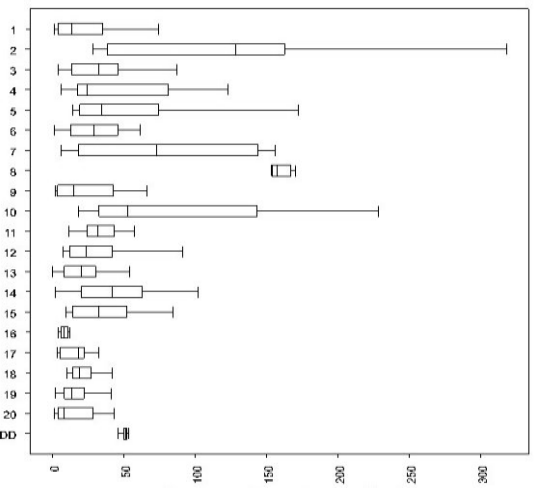

Figure 1. Box-plot for number of kernels per plant

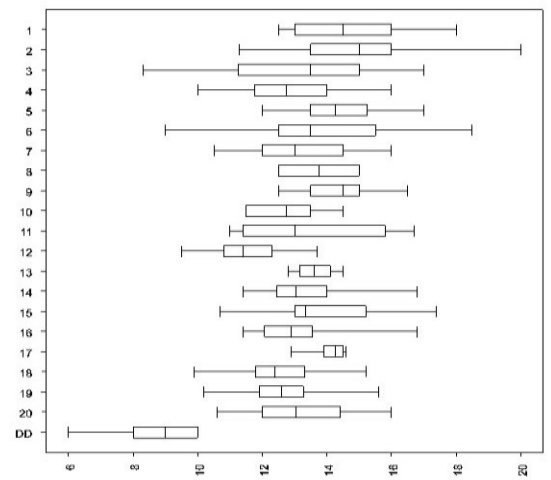

Figure 3. Box-plot for main spike length

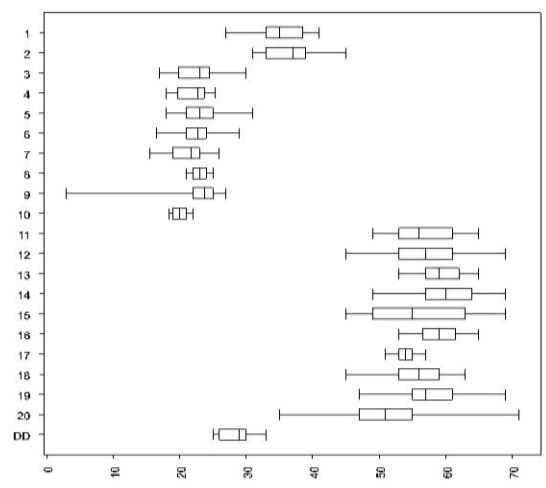

Figure 5. Box-plot for number of spikelets per main spike

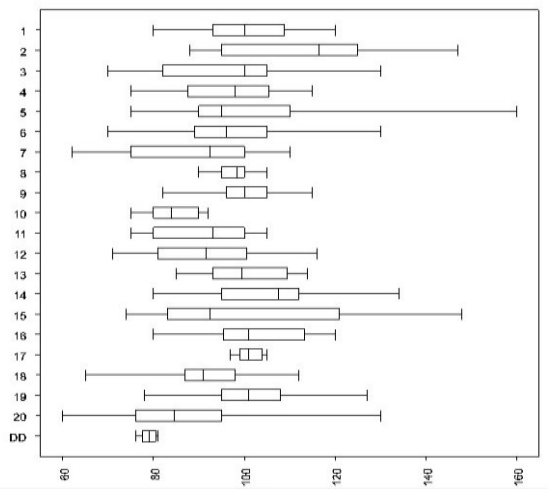

Figure 2. Box-plot for rachis length

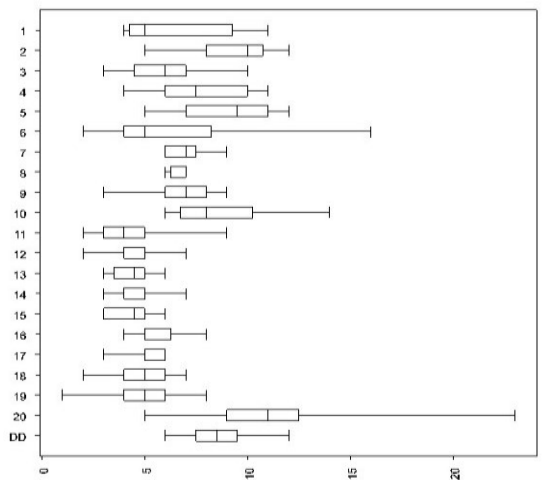

Figure 4. Box-plot for number of productive culms per plant

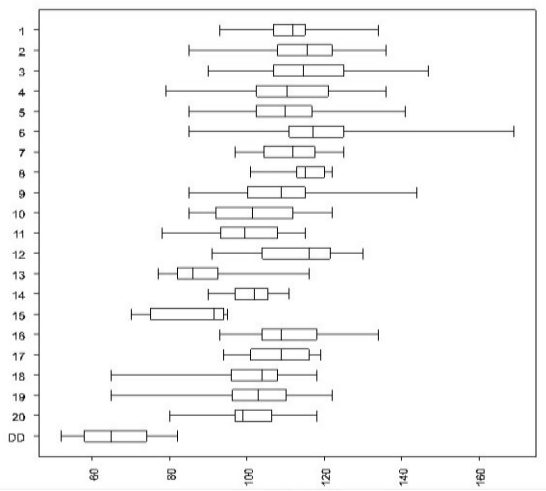

Figure 6. Box-plot for plant height 


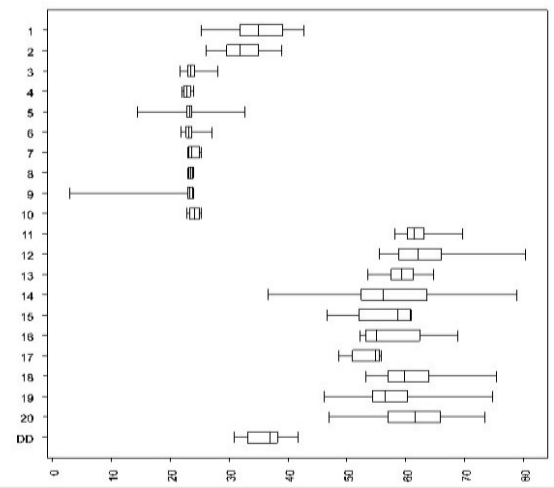

Figure 7. Box-plot for spike density (D)

Table 4. Correlation coefficients between quantitative traits of $\mathrm{F}_{1}$ interspecific hybrids in Secale genus

\begin{tabular}{lllllll}
\hline Trait & $\begin{array}{l}\text { Plant } \\
\text { height }\end{array}$ & $\begin{array}{l}\text { Number of } \\
\text { productive } \\
\text { culms per plant }\end{array}$ & $\begin{array}{l}\text { Main } \\
\text { spike } \\
\text { length }\end{array}$ & $\begin{array}{l}\text { Number of } \\
\text { spikelets per } \\
\text { main spike }\end{array}$ & $\begin{array}{l}\text { Rachis } \\
\text { length }\end{array}$ & $\begin{array}{l}\text { Spike } \\
\text { density } \\
\text { (D) }\end{array}$ \\
\hline $\begin{array}{l}\text { Number of productive } \\
\text { culms per plant }\end{array}$ & 0.03 & & & & \\
$\begin{array}{l}\text { Main spike length } \\
\text { Number of spikelets } \\
\text { per main spike }\end{array}$ & $0.62 * *$ & -0.02 & & & \\
$\begin{array}{l}\text { Rachis length } \\
\text { Spike density (D) }\end{array}$ & -0.28 & $-0.55^{* *}$ & -0.04 & & \\
$\begin{array}{l}\text { Number of kernels } \\
\text { per plant }\end{array}$ & -0.42 & -0.25 & $0.72 * * *$ & 0.20 & & \\
\hline & 0.19 & $-0.49 *$ & -0.16 & $0.98^{* * *}$ & 0.01 & \\
\hline
\end{tabular}

The greatest variability in terms of all of the analysed phenotypic traits jointly, represented by the greatest Mahalanobis distance, was recorded for the cross combinations Secale cereale ssp. cereale cv. Amilo $\times$ Secale cereale ssp. ancestrale and Secale cereale ssp. cereale cv. Dańkowskie Diament $\times$ Secale cereale ssp. dighoricum, with a Mahalanobis distance of 11.071, and for Secale cereale ssp. cereale cv. Amilo $\times$ Secale cereale ssp. ancestrale and Secale cereale ssp. dighoricum $\times$ Secale cereale ssp. cereale cv. Dańkowskie Diament, with variation expressed by a Mahalanobis distance of 11.051 (Table 5). 
Table 5. Mahalanobis distances between tested hybrid combinations and cv. Dańkowskie Diament

\begin{tabular}{cllllllllll}
\hline No. & \multicolumn{1}{c}{1} & \multicolumn{1}{c}{2} & \multicolumn{1}{c}{3} & \multicolumn{1}{c}{4} & \multicolumn{1}{c}{5} & \multicolumn{1}{c}{6} & \multicolumn{1}{c}{7} & \multicolumn{1}{c}{8} & \multicolumn{1}{c}{9} & 10 \\
\hline 1 & 0 & & & & & & & & & \\
2 & 4.076 & 0 & & & & & & & & \\
3 & 3.601 & 5.394 & 0 & & & & & & & \\
4 & 3.719 & 4.764 & 1.455 & 0 & & & & & & \\
5 & 4.065 & 4.287 & 2.519 & 1.421 & 0 & & & & & \\
6 & 3.137 & 4.83 & 1.571 & 1.397 & 1.784 & 0 & & & & \\
7 & 3.979 & 4.38 & 1.839 & 2.05 & 2.181 & 2.224 & 0 & & & \\
8 & 5.872 & 4.378 & 4.321 & 4.181 & 3.957 & 4.504 & 2.911 & 0 & & \\
9 & 3.066 & 4.816 & 1.965 & 1.734 & 2.062 & 1.157 & 2.439 & 4.977 & 0 & \\
10 & 4.741 & 5.052 & 2.253 & 2.426 & 2.794 & 3.187 & 1.543 & 3.367 & 3.357 & 0 \\
11 & 6.401 & 8.065 & 9.439 & 9.757 & 10.205 & 9.396 & 9.664 & 10.728 & 9.168 & 10.154 \\
12 & 6.737 & 8.522 & 9.655 & 9.882 & 10.437 & 9.591 & 10.119 & 11.051 & 9.53 & 10.557 \\
13 & 6.665 & 8.276 & 9.645 & 9.922 & 10.424 & 9.64 & 9.894 & 11.071 & 9.3 & 10.324 \\
14 & 6.371 & 7.696 & 9.408 & 9.587 & 10.069 & 9.334 & 9.638 & 10.553 & 9.13 & 10.092 \\
15 & 6.036 & 7.352 & 8.948 & 9.173 & 9.624 & 8.924 & 9.062 & 10.169 & 8.534 & 9.536 \\
16 & 6.114 & 8.156 & 9.256 & 9.462 & 9.977 & 9.112 & 9.755 & 10.93 & 9.025 & 10.178 \\
17 & 4.821 & 7.027 & 7.994 & 8.296 & 8.783 & 7.873 & 8.38 & 9.649 & 7.73 & 8.89 \\
18 & 6.129 & 8.008 & 9.14 & 9.405 & 9.926 & 9.103 & 9.519 & 10.676 & 8.892 & 9.95 \\
19 & 6.201 & 8.096 & 9.182 & 9.4 & 9.983 & 9.141 & 9.643 & 10.804 & 8.943 & 10.046 \\
20 & 5.776 & 7.465 & 8.813 & 8.936 & 9.124 & 8.681 & 9.004 & 10.431 & 8.463 & 9.218 \\
DD & 6.076 & 6.979 & 5.696 & 5.69 & 6.558 & 6.501 & 6.058 & 7.571 & 5.923 & 5.568 \\
\hline No. & 111 & 12 & 13 & 14 & 15 & 16 & 17 & 18 & 19 & 20 \\
\hline 11 & 0 & & & & & & & & & \\
12 & 2.213 & 0 & & & & & & & & \\
13 & 1.391 & 2.867 & 0 & & & & & & & \\
14 & 1.55 & 1.999 & 1.479 & 0 & & & & & & \\
15 & 1.806 & 3.382 & 1.202 & 1.798 & 0 & & & & & \\
16 & 2.491 & 1.842 & 2.738 & 2.089 & 3.377 & 0 & & & & \\
17 & 2.083 & 2.584 & 2.454 & 2.126 & 2.606 & 1.7 & 0 & & & \\
18 & 1.055 & 1.571 & 1.554 & 1.368 & 2.06 & 1.816 & 1.765 & 0 & & \\
19 & 1.889 & 1.602 & 1.77 & 1.256 & 2.368 & 1.4 & 1.848 & 1.028 & 0 & \\
20 & 3.94 & 4.698 & 4.343 & 4.453 & 4.435 & 3.94 & 3.594 & 3.818 & 4.293 & 0 \\
DD & 8.519 & 8.874 & 8.198 & 8.296 & 7.457 & 8.84 & 7.893 & 8.112 & 8.091 & 8.306 \\
\hline & & & & & & & & & & \\
\hline
\end{tabular}

On the other hand, the greatest phenotypic similarity was observed for the cross combinations Secale cereale ssp. segetale $\times$ Secale cereale ssp. cereale $\mathrm{cv}$. Skat and Secale cereale ssp. cereale cv. Skat $\times$ Secale cereale $\mathrm{ssp}$. segetale, for which the Mahalanobis distance was 1.028.

Multivariate analysis was used to compare the tested cross combinations and cultivar Dańkowskie Diament in terms of seven quantitative traits (Fig. 8). 


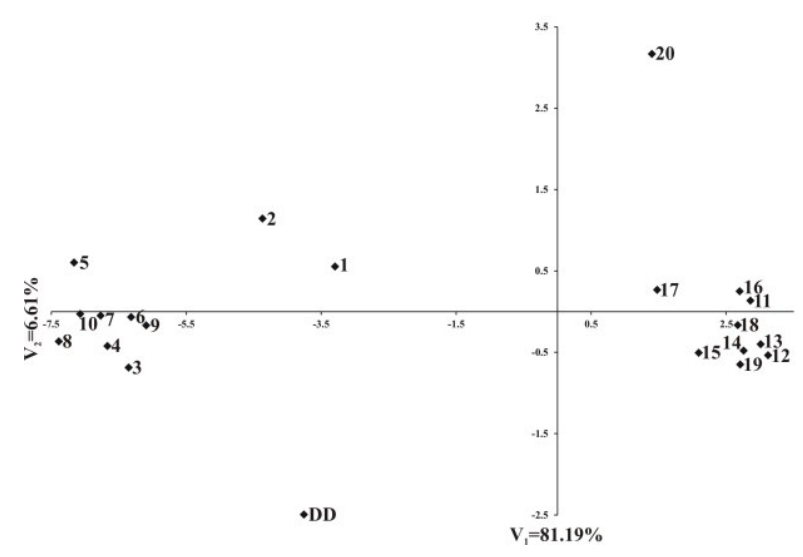

Figure 8. A comparison of $F_{1}$ crosses of rye and cv. Dańkowskie Diament in the system of canonical variables

The total variation explained by the first canonical variable was $81.19 \%$, while for the second variable it was $6.61 \%$. In the graph we may distinguish three groups of objects which exhibit considerable phenotypic similarity. The first group comprises hybrids coming from simple and reciprocal crossings between Secale cereale ssp. afghanicum $\times$ Secale cereale ssp. cereale cv. Amilo. The second group consists of hybrids produced by crossing of the cultivars Dańkowskie Diament and Skat with two wild subspecies, Secale cereale ssp. afghanicum and Secale cereale ssp. ancestrale, as well as simple and reciprocal crosses between Secale cereale ssp. ancestrale and cv. Amilo. The third group comprises all of the objects produced as a result of crossing of cultivars with the wild subspecies Secale cereale ssp. dighoricum and Secale cereale ssp. segetale. Both the control cultivar Dańkowskie Diament and the hybrid Secale vavilovii $\times$ Secale cereale ssp. cereale cv. Amilo differed from the other objects with respect to the analysed quantitative traits.

\section{Discussion}

The crop species Secale cereale ssp. cereale is a cereal grown mainly in Central and Eastern Europe, in areas requiring first of all tolerance of long and freezing 
winters and poor quality soils (sandy, acidified and with water deficits). Subspecies which constitute a potential source of new genetic variation for rye cultivars include Secale cereale ssp. afghanicum, ancestrale, dighoricum, segetale; to these may be added the species Secale vavilovii according to the taxonomic classification of Hammer (Hammer et al., 1987; Hammer, 1990). Over 22,000 rye genotypes are deposited in gene banks worldwide, of which three-quarters originate from European collections, and these forms may be used to enrich the gene pool of rye (Knüpffer, 2011). The collection of the genus Secale deposited at the PAS Botanical Garden and Centre for Biological Diversity Conservation comprises 2560 specimens - mainly local forms, cultivars and inbred lines of rye, with only 79 of them being wild forms. The wild species and subspecies used in crossings with three rye varieties came from the collection of the PAS Botanical Garden. Selected species and wild subspecies were exclusively annual forms (Kubicka et al., 2006).

Work on distant crossing in cereals, including rye, requires efficient techniques of hybrid production, effective identification of hybrid plants, breeding methods for such input materials, methods of assessment of hybrid stability and gene transfer potential, as well as observations of important economic traits. The efficiency of distant crossings is a factor limiting the applicability of crosses. In this study it ranged from $0 \%$ (no kernels for six combinations of simple and reciprocal crossings) to $51.4 \%$ in the combinations Secale cereale ssp. cereale cv. Dańkowskie Diament $\times$ Secale cereale ssp. ancestrale, while the mean crossing efficiency for all of the 20 combinations was 16.6\%. Mackiewicz-Karolczak and Broda (2002) obtained on average 4.4 kernels per 100 pollinated flowerets of their crosses, i.e. a four times lower efficiency of crossings with wild species and subspecies (Secale cereale ssp. afghanicum, ssp. ancestrale, ssp. segetale, S. sylvestre, S. vavilovii).

Materials deposited in the collections are described in terms of morphological traits. In the Polish collections of rye forms the greatest variation was observed for three traits, namely plant height $(30-200 \mathrm{~cm})$, spike length $(4-14.8 \mathrm{~cm})$ and TKW (Kubicka et al., 2006). A similar variability in plant 
height and spike length was observed in the $F_{1}$ generation, where plant height ranged from $86 \mathrm{~cm}$ to $118 \mathrm{~cm}$, while spike length deviated from the observations of Kubicka et al. (2006) and ranged from $11.6 \mathrm{~cm}$ to $14.9 \mathrm{~cm}$. The analysis of correlations for traits in the $F_{1}$ crosses showed a significant positive interdependence between plant height and length of the main spike. Ćwiklińska et al. (2009) indicated that traits significantly distinguishing the crop species from wild rye species and subspecies included the number of spikelets in the main spike and the number of kernels per spike.

The potential for the application of wild species as a source of variation for the generation of new input materials and further breeding requires observations of several yield-forming traits, influencing the economic traits of cultivars. For rye these include such traits as plant height, the number of productive culms, the length of the main spike, spike density and the number of kernels per spike. Mackiewicz and Broda (2004) observed that the crosses they produced were taller than the control cultivar Dańkowskie Złote, similarly as in the results presented here, where the control cultivar Dańkowskie Diament was less tall than the 20 analysed cross combinations. Śmiałowski and Węgrzyn (2003) indicated that heritability sensu stricto $h^{2}$ (w) was low for most investigated traits (plant height, the number of kernels per spike, spike length) except for the number of kernels per spike, shank length and TKW, while heritability sensu lato $h^{2}$ (s) was high for most investigated traits. The authors pointed out that the establishment of advantageous traits may be difficult in view of the low heritability of certain traits. In this study $F_{1}$ hybrids showed statistically significant negative correlations for such traits as the number of spikelets in the main spike with the number of productive culms, the number of productive culms with spike density, as well as spike density with the number of kernels per plant, which confirms the observations reported by Śmiałowski and Węgrzyn (2003) and may limit the potential applicability of crosses of rye cultivars with wild species and subspecies as sources of genetic variation.

For a species with a limited genetic pool, such as rye, distant crossings remain necessary sources of genes for economic traits. Some of the most 
important groups of genes searched for in wild rye forms include genes of resistance to biotic stresses - resistance to diseases and pests, genes related to abiotic stresses, as well as cytoplasmic male sterility and restorers for heterosis breeding. Further issues currently of primary concern in the selection process relate to the improvement of quality attributes, particularly those affecting flour strength and the nutritive value of rye products as a functional food preventing diseases of civilisation or lifestyle.

\section{Conclusion}

Observations of biometric traits indicate that the $F_{1}$ crosses produced may be potential sources of variation for common rye.

- The greatest variation in terms of all analysed phenotypic traits combined was found for the cross combinations Secale cereale ssp. cereale cv. Amilo $\times$ Secale cereale ssp. ancestrale and Secale cereale ssp. cereale cv. Dańkowskie Diament $\times$ Secale cereale ssp. dighoricum.

- Hybrids of the $F_{1}$ generation showed considerable variation in the analysed biometric traits within individual cross combinations.

\section{Acknowledgements:}

This research was funded by KBN grant no. N N310 308034.

\section{REFERENCES}

Caliński T., Kaczmarek Z. (1973): Metody kompleksowej analizy doświadczenia wielocechowego [Methods of comprehensive analysis of a multi-variate experiment]. Colloquium Metodologiczne z Agro-Biometrii 3: 258-320.

Ćwiklińska A., Broda Z., Bocianowski J. (2009): Analiza porównawcza cech dzikich gatunków rodzaju Secale L. w celu poszerzenia zmienności genetycznej przydatnej $\mathrm{w}$ hodowli [Comparative analysis of the features of wild species within the genus Secale for widening genetic variability to be utilized in breeding]. Biul. IHAR 252:119-137.

Falke K.C., Sušić Z., Hackauf B., Korzun V., Schondelmaier J., Wilde P., Wehling P., Wortmann H., Mank, Rouppe van der Voort J., Maurer H.P., Miedaner T., Geiger H.H. (2008): Establishment of introgression libraries in hybrid rye (Secale cereale 
L.) from an Iranian primitive accession as a new tool for rye breeding and genomics. Theor Appl Genet 117: 641-652.

Feuillet C., Langridge P., Waugh R. (2007): Cereal breeding takes a walk on the wild side. Trends in Genetics 24(1): 24-32.

Geiger H.H., Miedaner T. (2009): Rye breeding. In: M.J. Carena (ed.) Cereals. Springer Science + Business Media, LLC 2009: 157-181.

Hammer K., Skolimowska E., Knüpffer H. (1987): Vorarbeiten zur monographischen Darstellung von Wild-pflanzensortimenten: Secale L. Kulturpflanze 35: 135-177.

Hammer K. (1990): Breeding system and phylogenetic relationships in Secale L. Biol. Zent. 109(1): 45-50.

Jankiewicz M. (2006): Ewolucja koncepcji wykorzystania zbóż w gospodarce i żywieniu człowieka [Evolution of the concept of using cereals in the economy and as a food for humans]. Hodowla Roślin i Nasiennictwo 4: 5-8.

Knüpffer H. (2011): Rye Genetic Resources in the World's Genebanks. In: International Conference "More Attention to Rye", October 6-8, Tartu, Estonia and The AEGIS Workshop "Improving the prerequisites for a European rye collection", October 13-14, Radzików, Poland

Kubicka H., Puchalski J., Niedzielski M., Łuczak W., Martyniszyn. (2006) Gromadzenie i ocena zasobów genowych żyta [Collecting and evaluation of genetic resources of rye]. Biul. IHAR 240/241: 141-149.

Mackiewicz D., Broda Z. (2004): Ocena przydatności hodowlanej mieszańców żyta uprawnego Secale cereale L. z dzikimi gatunkami z rodzaju Secale [Estimation of breeding suitability of hybrids of rye (Secale cereale L.) with wild species from the genus Secale]. Biul. IHAR 231: 265-277.

Mackiewicz-Karolczak D., Broda Z. (2002): Ocena efektywności krzyżowań międzygatunkowych w rodzaju Secale [Estimation of the efficiency of interspecific crosses in genus Secale]. Biul. IHAR 221: 73-82.

Mahalanobis P. C. (1936): On the generalized distance in statistics. Proceedings on the National Institute of Science of India 12: 49-55.

Payne R., Murrey D., Harding S., Baird D., Soutou D. (2012): Introduction to GenStat for Windows (15th Edition). VSN International, Hemel Hempstead, England.

Pilch J. (2011): Introgresje genów z gatunków spokrewnionych taksonomicznie w ulepszeniach pszenicy Triticum aestivum L. i innych roślin uprawnych [Introgressions of genes from taxonomically related species in improvement of wheat Triticum aestivum L. and other cultivated plants]. Biul. IHAR 260/261: 21-42.

Rencher A.C. (1992): Interpretation of canonical discriminant functions, canonical variates, and principal components. Am. Stat. 46: 217-225.

Seidler-Łożykowska K., Bocianowski J. (2012): Evaluation of variability of morphological traits of selected caraway (Carum carvi L.) genotypes. Ind. Crops Prod. 35: 140-145.

Śmiałowski T., Węgrzyn S. (2003): Genetyczno-statystyczne parametry dziedziczenia cech użytkowych żyta ozimego (Secale cereale L.) [The genetic and statistical analysis of the heritability of important traits in winter rye (Secale cereale L.)]. Biul. IHAR 230: 205-214. 